\title{
Hubungan tingkat pengetahuan kesehatan gigi dan mulut dengan status kesehatan jaringan periodontal pada penyandang diabetes melitus tipe 2 di RSUD Manembo-nembo Bitung
}

\author{
${ }^{1}$ Dian P. Lestari \\ ${ }^{2}$ Vonny. N. S. Wowor \\ ${ }^{2}$ Elita Tambunan
}

\author{
${ }^{1}$ Kandidat Skripsi Program Studi Pendidikan Dokter Gigi Fakultas Kedokteran \\ ${ }^{2}$ Program Studi Pendidikan Dokter Gigi Fakultas Kedokteran \\ Universitas Sam Ratulangi Manado \\ E-mail: lestarid050@gmail.com
}

\begin{abstract}
Oral health is very important because it can influence our daily activities and other parts of the body. Periodontal disease occurs in the supporting structures of teeth that can cause tooth loose as well as tooth loss. The relationship between periodontal disease and some systemic diseases such as type 2 diabetes mellitus (T2DM) is increasing over the past years. Public knowledge of T2DM and the relationship of this disease and periodontal disease is still poor. This study was aimed to obtain the relationship between the level of knowledge of oral and dental health and the status of periodontal tissues in patients of T2DM. This was a descriptive analytical study with a cross-sectional design. This study was conducted at RSUD Manembo-nembo Bitung. Respondents were 65 patients of T2DM who completed the questionnaires and their periodontal status were examined. The results showed that $52.3 \%$ of patients had unvaforable category of knowledge of dental and oral health and $83.1 \%$ had periodontal status in gingivitis category. The chi-square test showed a $p$ value of 0.001 ( $p$ <0.05). Conclusion: There was a significant relationship between the level of knowledge of oral dan dental health and the periodontal status of T2DM patients at RSUD Manembo-nembo Bitung.
\end{abstract}

Keywords: the level of, periodontal status, type 2 diabetes mellitus

\begin{abstract}
Abstrak: Kesehatan gigi dan mulut merupakan hal yang sangat penting untuk diperhatikan, karena hal ini bisa menyebabkan gangguan aktifitas sehari-hari, bahkan mengganggu kesehatan tubuh lainnya. Penyakit periodontal mengenai jaringan pendukung gigi yang dapat menyebabkan gigi goyang bahkan tanggal. Hubungan antara penyakit periodontal dan beberapa penyakit sistemik seperti diabetes melitus tipe 2 (DMT2) meningkat beberapa tahun ini, salah satunya akibat rendahnya pengetahuan masyarakat terhadap penyakit tersebut dan hubungan dengan penyakit periodontal. Penelitian ini bertujuan untuk mengetahui hubungan tingkat pengetahuan kesehatan gigi dan mulut dan status jaringan periodontal pada penyandang DMT2. Jenis penelitian yaitu deskriptif analitik dengan desain potong lintang. Penelitian dilaksanakan di RSUD Bitung dengan responden berjumlah 65 penyandang DMT2, yang diperiksa status periodontal dan pengisian kuesioner. Hasil penelitian menunjukkan bahwa pengetahuan responden mengenai kesehatan gigi dan mulut dalam kategori kurang baik sebesar 52,3\% dengan status periodontal yaitu kategori gingivitis sebesar 83,1\%. Berdasarkan hasil uji chi-square didapatkan nilai $\mathrm{p}=0,001 \quad(\mathrm{p}<0,05)$. Simpulan: Terdapat hubungan bermakna antara tingkat pengetahuan kesehatan gigi dan mulut dengan status periodontal pada penyandang DMT2 di RSUD Manembo-nembo Bitung.
\end{abstract}

Kata kunci: tingkat pengetahuan, status periodontal, DMT2 
Sehat menurut World Health Organization (WHO) merupakan suatu keadaan yang sempurna baik secara fisik, mental, sosial, dan bahkan bebas dari penyakit atau kecacatan. ${ }^{1}$ Kesehatan gigi dan mulut merupakan gerbang awal bagi kesehatan tubuh secara keseluruhan. Kesehatan gigi dan mulut merupakan hal yang sangat penting untuk diperhatikan, karena hal ini bisa menyebabkan gangguan aktifitas sehari-hari, bahkan dapat mengganggu kesehatan tubuh lainnya.

Data Riset Kesehatan (RISKESDAS) tahun 2013 menunjukkan prevalensi nasional masalah gigi dan mulut sebesar $25,9 \%$ dan sebanyak 14 provinsi mempunyai prevalensi masalah gigi dan mulut di atas angka nasional. Provinsi Sulawesi Utara merupakan salah satu provinsi dengan prevalensi sebesar $31,6 \%{ }^{2}$ Penyakit karies dan penyakit periodontal merupakan dua penyakit gigi dan mulut yang merupakan masalah utama bagi kesehatan gigi dan mulut di Indonesia. Prevalensi penyakit periodontal pada semua kelompok umur di Indonesia yaitu $96,58 \% .^{3}$

Penyakit periodontal mengenai jaringan pendukung gigi, yang dapat menyebabkan gigi goyang bahkan tanggal. Menyikat gigi yang salah, kebiasaan buruk merokok, faktor kehamilan serta gangguan sistemik diabetes melitus, antara lain merupakan faktor risiko terhadap terjadinya penyakit periodontal. Hubungan antara penyakit periodontal dan beberapa penyakit sistemik seperti diabetes melitus meningkat beberapa tahun ini. ${ }^{4}$

Diabetes melitus tipe 2 (DMT2) merupakan penyakit gangguan metabolik yang ditandai oleh kenaikan gula darah akibat penurunan sekresi insulin oleh sel beta pankreas ataupun gangguan fungsi insulin (resistensi insulin). ${ }^{5}$ Menurut Rikawarastuti ${ }^{6}$ diabetes melitus memiliki hubungan signifikasi dengan tingkat keparahan periodontal. Kelompok DMT2 lebih berisiko 3,505 kali mengalami keparahan jaringan periodontal dibandingkan dengan kelompok non DMT2. ${ }^{6}$ Penyakit periodontal pada pasien DMT2 lebih parah dibandingkan pada pasien non DMT2. $^{7}$

Rendahnya pengetahuan masyarakat terhadap penyakit DMT2 dan hubungannya dengan penyakit periodontal ditunjukkan dalam penelitian di Saudi Arabia tahun 2011. Penelitian ini menunjukkan bahwa pasien DMT2 memiliki pengetahuan yang kurang tentang peningkatan risiko mereka terhadap penyakit mulut dan tentang adanya komplikasi oral yang berhubungan dengan kesehatan rongga mulut. ${ }^{8}$ Salah satu komplikasi DMT2 yang cukup sering di bidang kedokteran gigi yaitu oral diabetic, yang meliputi mulut kering, gusi mudah berdarah (gingivitis), kalkulus, resorbsi tulang alveolaris, peridontitis, dan lain sebagainya. Dari sekian banyak komplikasi yang terjadi periodontitis merupakan komplikasi yang paling sering terjadi pada penderita diabetes melitus dengan tingkat prevelensi yang tinggi hingga mencapai angka $75 \% .^{9}$

Penelitian sebelumnya oleh Emor dan Pandelaki ${ }^{10}$ tentang status periodontal pasien Diabetes Melitus di Poliklinik Endokrin RSUP Prof. Dr. R. D. Kandou Manado menunjukkan bahwa sebanyak $56,8 \%$ memiliki status periodontal yang buruk.

Bitung merupakan kota yang berkembang di daerah Sulawesi Utara dan Rumah Sakit Umum Daerah Manembonembo Bitung merupakan rumah sakit terbesar di daerah Bitung. Dari hasil survei awal yang dilakukan oleh peneliti, Rumah Sakit Umum Daerah Bitung memiliki pasien DMT2 yang cukup banyak dan belum pernah dilakukan penelitian tentang diabetes terhadap jaringan periodontal.

Penelitian ini bertujuan untuk mendapatkan hubungan tingkat pengetahuan kesehatan gigi dan mulut dengan status kesehatan jaringan periodontal pada penderita DMT2 di RSUD Manembo-nembo Bitung

\section{BAHAN DAN METODE PENELITIAN}

Jenis penelitian ini ialah deskriptif analitik dengan desain potong lintang. Penelitian dilaksanakan di RSUD 
Manembo-nembo Bitung pada bulan Juli Agustus 2016. Populasi pada penelitian ialah penyandang DMT2 yang menjalani rawat jalan di RSUD Manembo-nembo Bitung dengan jumlah populasi 184 pasien. Sampel pada penelitian yaitu penyandang DMT2yang memenuhi kriteria inklusi dan eksklusi. Metode pengambilan sampel yaitu purposive sampling. dengan besar sampel sebanyak 65 responden. Pengambilan data diperoleh melalui kuesioner dan pemeriksaan status periodontal. Data pendukung yang diperoleh dari RSUD Manembo Nembo Bitung berupa jumlah pasien DMT2 di Poliklinik Penyakit Dalam.

\section{HASIL PENELITIAN}

Tabel 1. Distribusi responden berdasarkan jenis kelamin

\begin{tabular}{clr}
\hline Jenis kelamin & $\mathrm{n}$ & $\%$ \\
\hline $\mathrm{L}$ & 28 & 43,08 \\
$\mathrm{P}$ & 37 & 56,92 \\
Total & 65 & 100 \\
\hline
\end{tabular}

Tabel 2. Distribusi subjek berdasarkan usia

\begin{tabular}{ccc}
\hline Usia (tahun) & n & \% \\
\hline $12-25$ & 0 & 0 \\
$26-45$ & 12 & 18,46 \\
$>46$ & 53 & 81,54 \\
Total & 65 & 100 \\
\hline
\end{tabular}

Tabel 3. Distribusi subjek berdasarkan pendidikan terakhir

\begin{tabular}{clr}
\hline $\begin{array}{c}\text { Pendidikan } \\
\text { terakhir }\end{array}$ & n & \multicolumn{1}{c}{$\%$} \\
\hline SD/MI & 28 & 9,23 \\
SMP/MTs & 10 & 15,38 \\
SMA/MA & 32 & 49,23 \\
Diploma & 1 & 1,54 \\
Sarjana & 13 & 20 \\
Pasca Sarjana & 3 & 4,62 \\
Total & 65 & 100 \\
\hline
\end{tabular}

Tabel 4. Distribusi subjek berdasarkan pekerjaan.

\begin{tabular}{clr}
\hline Pekerjaan & n & \multicolumn{1}{c}{$\%$} \\
\hline Tidak bekerja & 19 & 29,23 \\
Tenaga honorer & 1 & 1,54 \\
Pensiunan & 9 & 13,85 \\
Wiraswasta & 8 & 12,30 \\
Swasta & 15 & 23,08 \\
PNS & 10 & 15,38 \\
TNI/Polri & 3 & 4,62 \\
Total & 65 & 100 \\
\hline
\end{tabular}

Tabel 5. Distribusi subjek penelitian berdasarkan penilaian tingkat pengetahuan kesehatan gigi dan mulut

\begin{tabular}{ccc}
\hline $\begin{array}{c}\text { Tingkat } \\
\text { pengetahuan }\end{array}$ & n & $\%$ \\
\hline Baik & 31 & 47,69 \\
Kurang Baik & 34 & 52,31 \\
Total & 65 & 100 \\
\hline
\end{tabular}

Tabel 6. Distribusi subjek penelitian berdasarkan pengetahuan kesehatan gigi dan mulut

\begin{tabular}{|c|c|c|c|c|c|}
\hline \multirow{2}{*}{ No } & \multirow{2}{*}{ Pertanyaan } & \multicolumn{2}{|c|}{ Ya } & \multicolumn{2}{|c|}{ Tidak } \\
\hline & & $\mathrm{n}$ & $\%$ & $\mathrm{n}$ & $\%$ \\
\hline 1 & $\begin{array}{l}\text { Apakah saudari/saudari tahu bahwa kebersihan gigi dan mulut } \\
\text { harus dijaga agar gigi dan mulut tetap sehat? }\end{array}$ & 62 & 95,38 & 3 & 4,62 \\
\hline 2 & $\begin{array}{l}\text { Apakah saudara/saudari tahu bahwa gigi dan mulut yang } \\
\text { kurang bersih dapat merupakan faktor risiko timbulnya } \\
\text { beberapa penyakit rongga mulut? }\end{array}$ & 56 & 86,15 & 9 & 13,85 \\
\hline 3 & $\begin{array}{l}\text { Apakah saudara/saudari tahu bahwa penyakit gigi dan mulut } \\
\text { merupakan salah satu gangguan yang timbul akibat gigi dan } \\
\text { mulut yang kurang bersih? }\end{array}$ & 54 & 83,08 & 11 & 16,92 \\
\hline 4 & $\begin{array}{l}\text { Apakah saudara/saudari tahu bahwa peradangan pada gusi } \\
\text { yang parah dapat berlanjut pada kerusakan jaringan penunjang } \\
\text { gigi lainnya? }\end{array}$ & 16 & 24,62 & 49 & 75,38 \\
\hline 5 & $\begin{array}{l}\text { Apakah saudara/saudari tahu bahwa penyakit Diabetes Melitus } \\
\text { tipe } 2 \text { dapat memengaruhi kesehatan gigi dan mulut? }\end{array}$ & 10 & 15,38 & 55 & 84,62 \\
\hline 6 & $\begin{array}{l}\text { Apakah saudara/saudari tahu bahwa penyakit Diabtes Melitus } \\
\text { tipe } 2 \text { dapat memperparah peradangan di gusi? }\end{array}$ & 8 & 12,30 & 57 & 87,70 \\
\hline
\end{tabular}


7 Apakah saudara/saudari tahu bahwa menyikat gigi merupakan salah satu menjaga kebersihan gigi dan mulut yang murah dan mudah dilakukan?

8 Apakah saudara/saudari tahu bahwa frekuensi menyikat gigi minimal 2 kali sehari?

$\begin{array}{rrrr}59 & 90,77 & 6 & 9,23 \\ 32 & 49,23 & 33 & 50,77 \\ 15 & 23,08 & 50 & 76,92 \\ 9 & 13,85 & 56 & 86,15\end{array}$

10 Apakah saudara/saudari tahu bahwa cara menyikat gigi yang baik dilakukan dengan metode gabungan, yaitu secara vertikal, horizontal, dan roll?

Tabel 7. Distribusi status periodontal subjek penelitian berdasarkan Periodontal Disesase Index (PDI)

\begin{tabular}{cccc}
\hline PDI & Status periodontal & $\mathbf{N}$ & \% \\
\hline 0 & Sehat & 0 & 0 \\
$1-3$ & Gingivitis & 54 & 83,08 \\
$4-6$ & Periodontitis & 11 & 16,92 \\
& Total & 65 & 100 \\
\hline
\end{tabular}

Tabel 8. Distribusi status kesehatan jaringan periodontal berdasarkan tingkat pengetahuan kesehatan gigi dan mulut

\begin{tabular}{|c|c|c|c|c|c|c|c|c|}
\hline \multirow{3}{*}{ Pengetahuan } & \multicolumn{6}{|c|}{ Periodontal Disease Index } & \multirow{2}{*}{\multicolumn{2}{|c|}{ Jumlah }} \\
\hline & \multicolumn{2}{|c|}{ Sehat } & \multicolumn{2}{|c|}{ Gingivitis } & \multicolumn{2}{|c|}{ Periodontitis } & & \\
\hline & $\mathrm{n}$ & $\%$ & $\mathrm{n}$ & $\%$ & $\mathrm{n}$ & $\%$ & $\mathrm{n}$ & $\%$ \\
\hline Baik & 0 & 0 & 31 & 47,69 & 0 & 0 & 31 & 47,69 \\
\hline Kurang & 0 & 0 & 23 & 35,39 & 11 & 16,92 & 34 & 52,31 \\
\hline & & & & & & Total & 65 & 100 \\
\hline
\end{tabular}

Tabel 9. Hubungan tingkat pengetahuan dan status periodontal

Chi-Square Tests

\begin{tabular}{|l|r|r|r|}
\hline & \multicolumn{1}{|c|}{ Value } & df & \multicolumn{2}{|c|}{ Asymp. Sig. (2-sided) } \\
\hline Pearson Chi-Square & $12.072^{\mathrm{a}}$ & 1 & .001 \\
Continuity Correction $^{\mathrm{b}}$ & 9.881 & 1 & .002 \\
Likelihood Ratio & 16.300 & 1 & .000 \\
Fisher's Exact Test & & & .001 \\
Linear-by-Linear & 11.887 & & \\
Association & & & \\
N of Valid Cases & 65 & & \\
\hline
\end{tabular}

\section{BAHASAN}

Hasil penelitian yang dilakukan pada penyandang DMT2 yang menjalani rawat jalan di Poliklinik Interna RSUD Bitung, menunjukkan bahwa sebagian besar $(52,31 \%)$ memiliki tingkat pengetahuan yang kurang baik. Berdasarkan kuesioner yang berisi 10 pertanyaan yang diajukan kepada 65 penyandang DMT2, hasilnya menunjukkan hampir seluruh responden $(95,38 \%)$ mengetahui bahwa kebersihan gigi dan mulut harus dijaga agar gigi dan mulut tetap sehat. Sebagian besar $(90,77 \%)$ mengetahui bahwa tindakan menyikat gigi merupakan salah satu cara menjaga kebersihan gigi dan mulut yang mudah dilakukan dan murah atau tidak membutuhkan biaya yang mahal. Umumnya mengetahui bahwa gigi dan mulut yang kurang bersih dapat merupakan faktor resiko timbulnya beberapa penyakit rongga mulut $(86,15 \%)$ dan sebanyak 
$83,08 \%$ mengetahui bahwa penyakit gigi dan mulut merupakan salah satu gangguan yang timbul akibat gigi dan mulut yang kurang bersih. Secara umum terlihat bahwa pengetahuan responden penelitian tentang kesehatan gigi dan mulut sudah tergolong baik. Responden telah memiliki kesadaran bahwa kesehatan gigi dan mulut harus dijaga agar tetap bersih dan sehat. Pada penelitian ini sebagian besar responden berpendidikan di atas SMA/MA. (Tabel 4) dan bahkan seluruhnya telah dewasa dari segi usia ((Tabel 3). Semakin tinggi tingkat pendidikan dan semakin dewasa usia seseorang, maka akan memengaruhi juga pengetahuan yang dimilikinya oleh karena kemampuannya untuk menerima informasi yang lebih baik. Hal ini sejalan dengan pembahasan Herijulianti et al. ${ }^{11}$ bahwa semakin kompleks pendidikan pada orang dewasa, maka akan lebih menuntun individu untuk meningkatkan pengetahuan dan mengembangkan kemampuannya. Berdasarkan wawancara dengan responden penelitian diperoleh informasi bahwa pengetahuan yang mereka miliki diperoleh dari media elektronik berupa iklan kesehatan gigi di televisi. Di samping itu berbagai informasi diperoleh juga lewat media cetak berupa tulisan dan iklan dalam surat kabar.

Berdasarkan hasil kuesioner mengenai cara merawat kesehatan gigi dan mulut menunjukkan sebagian responden $(86,25 \%)$ tidak mengetahui cara menyikat gigi yang baik yang dilakukan dengan metode gabungan. Metode gabungan merupakan perpaduan antara teknik menyikat secara vertikal, horizontal, dan roll. Data hasil penelitian juga menunjukkan sebagian responden $(76,92 \%)$ juga kurang mengetahui tentang waktu menyikat gigi yang baik, yaitu dilakukan setelah sarapan dan sebelum tidur malam, serta sekitar setengah $(50,77 \%)$ dari jumlah keseluruhan responden yang tidak mengetahui bahwa frekuensi menyikat gigi yang baik minimal $2 \mathrm{x}$ sehari. Hasil yang ada memperlihatkan bahwa subjek penelitian umumnya memiliki pengetahuan yang baik berkaitan dengan kesehatan gigi dan mulut, namun memiliki pengetahuan yang kurang baik berkaitan dengan cara memelihara kebersihan gigi dan mulut. Menurut penulis pengetahuan yang baik yang dimiliki responden tentang kesehatan gigi dan mulut masih bersifat umum. Pengetahuan tentang kesehatan gigi dan mulut yang bersifat umum bisa diperoleh lewat media cetak, elektronik ataupun lewat media internet. Saat ini banyak iklan-iklan masyarakat tentang kesehatan gigi dan mulut, namun tentang teknis pemeliharaan gigi dan mulut masih kurang. Biasanya pengetahuan ini diperoleh lewat penyuluhan yang dilakukan oleh tenaga kesehatan. Penyuluhan tentang kesehatan gigi dan mulut biasanya dilakukan oleh tenaga kesehatan gigi yang ada di puskesmas, namun karena kurangnya tenaga dokter gigi atau penyebaran tenaga dokter gigi yang kurang merata menyebabkan tenaga perawat gigi di puskesmas lebih banyak bekerja di poliklinik puskesmas dibandingkan menyuluh ke masyarakat. Hasil tanya jawab atau wawancara dengan responden penelitian didapatkan bahwa cukup banyak yang melakukan sikat gigi hanya sekali dalam sehari dengan alasan sibuk dengan urusan atau pekerjaan rumah tangga. Sebagian besar respoden ialah ibu rumah tangga $(29,23 \%)$ dan waktu mereka tersita dengan aktivitas atau pekerjaan dalam rumah tangga. Di samping itu ada juga yang menyikat gigi sekali saja dalam sehari karena banyak beraktivitas di luar rumah dan ketika pulang dengan kondisi tubuh yang lelah menyebabkan malas untuk menyikat gigi.

Data yang ada menunjukkan $49,23 \%$ tahu bahwa menyikat gigi yang baik dilakukan dua kali sehari, namun hanya sebesar $13,85 \%$ yang mengetahui cara menyikat gigi yang baik. Walaupun responden mengetahui frekuensi menyikat gigi yang baik, tetapi kebersihan gigi dan mulut tidak hanya ditentukan oleh frekuensi menyikat gigi saja. Gigi dan mulut yang bersih ditentukan juga oleh 
waktu penyikatan gigi dilakukan. Waktu yang baik yakni sesudah sarapan dan malam hari sebelum tidur. Hasil yang ada menunjukkan hanya sebagian kecil yang tahu bahwa menyikat gigi yang baik dilakukan setelah sarapan dan sebelum tidur malam $(23,08 \%)$. Demikian halnya juga dengan teknik menyikat gigi turut memengaruhi kebersihan gigi dan mulut individu. Gigi dan mulut yang kurang terjaga kebersihannya dapat menyebabkan gangguan pada jaringan periodontal yang biasanya diawali dengan inflamasi pada gingiva (gingivitis). Kurangnya subjek penelitian yang memahami cara menyikat gigi yang baik akan memengaruhi kondisi status kesehatan jaringan periodontalnya. Menyikat gigi dengan cara yang benar dan dilakukan secara teratur dapat mengontrol plak pada permukaan gigi sehingga dapat mencegah terjadinya gangguan pada gigi dan jaringan pendukung gigi atau periodontal. ${ }^{12}$ Hal ini juga sejalan dengan penelitian Fitriyani $^{13}$ yang melaporkan bahwa masih adanya tingkat pengetahuan yang rendah terhadap perilaku mengosok gigi. Sebanyak $(24,62 \%)$ tidak mengetahui bahwa peradangan pada gusi yang parah dapat berlanjut pada kesehatan jaringan penunjang gigi lainnya. Hal ini menggambarkan bahwa responden belum mengetahui bahwa penyakit DMT2 bisa memperparah perandangan gusi.

Secara umum hampir seluruh responden $(87,70 \%)$ tidak mengetahui penyakit diabetes melitus dapat memperparah peradangan di gusi dan $84,62 \%$ tidak mengetahui penyakit DMT2 dapat memengaruhi kesehatan gigi dan mulut.. Hal ini menggambarkan bahwa banyak responden yang belum tahu tentang dampak penyakit diabetes melitus terhadap kesehatan gigi dan mulut. Hal ini sejalan dengan hasil penelitian Eldarrat ${ }^{8}$ yang menyatakan bahwa masih rendahnya pengetahuan masyarakat terhadap penyakit DMT2 dan hubungannya dengan penyakit periodontal. ${ }^{8}$ Informasi tentang DMT2 atau penyakit sistemik yang berkaitan dengan kesehatan gigi dan mulut belum luas dikenal oleh kalangan masyarakat.
Kurangnya informasi dari dokter umum maupun dokter spesialis penyakit dalam tentang keterkaitan penyakit DMT2 dengan kesehatan rongga mulut yang disampaikan kepada penderita yang dirawat, turut menentukan tingkat pengetahuan penyandang DMT2 berkaitan dengan dampaknya pada kesehatan gigi dan mulut.

Pengetahuan merupakan faktor predisposisi terjadinya suatu perilaku. Penelitian dan pengalaman membuktikan bahwa perilaku yang didasari pengetahuan akan lebih bermakna dari pada perilaku yang tidak didasari oleh pengetahuan. ${ }^{14}$ Pada penelitian ini responden memiliki pengetahuan yang minim berkaitan dengan penyakit DMT2 dan hubungannya dengan kesehatan gigi dan mulut. Hal ini akan memengaruhi perilaku responden dalam menjaga kesehatan gigi dan mulutnya.

Berdasarkan hasil pemeriksaan status kesehatan jaringan periodontal, menunjukkan bahwa hampir seluruh responden $(83,08 \%)$ memiliki status periodontal gingivitis. Kondisi ini mungkin saja berhubungan dengan kurangnya pengetahuan responden berkaitan dengan teknik/cara menyikat gigi, frekuensi menyikat gigi, dan waktu menyikat gigi, yang dapat memengaruhi pembentukan plak pada permukaan gigi. Kebersihan gigi dan mulut yang kurang terjaga menyebabkan timbulnya lapisan plak yang menempel di permukaan gigi dan lamakelamaan mengeras atau terbentuk karang gigi (kalkulus). Kalkulus bisa juga menempel pada permukaan akar gigi dan dapat menyebabkan terjadinya gangguan pada kesehatan jaringan periodontal yang biasanya diawali dengan peradangan pada gingiva (gingivitis). Gingivitis yang kurang mendapatkan perawatan yang baik akan menjadi parah dan menyebabkan periodontitis dan bahkan kerusakan pada jaringan periodontal dan mengakibatkan gigi mudah tanggal. Hasil penelitian ini sejalan dengan penelitian yang dilakukan oleh Anthonie ${ }^{15}$ yang menyatakan bahwa penyebabnya terjadinya gingivitis pada penderita disebabkan kurangnya menjaga 
dan merawat kebersihan gigi dan mulut sehingga mudah berkembang biak dan menyebabkan terjadinya gingivitis.

Penyandang diabetes melitus sangat rentan terhadap masalah kesehatan gigi dan mulut; hal ini karena kandungan glukosa yang tinggi di dalam cairan gingiva dan darah yang dapat mengubah lingkungan mikroflora dalam mulut, meliputi perubahan kualitatif bakteri yang berpengaruh terhadap keparahan pada kesehatan gigi dan mulut. ${ }^{16}$ Di samping itu dampak penyakit diabetes dalam mulut berupa berkurangnya jumlah saliva dalam mulut sehingga mulut menjadi kering (xerostomia) merupakan faktor risiko terhadap adanya gangguan periodontal karena kurangnya efek self cleansing dikarenakan saliva yang berkurang. ${ }^{17}$

Berdasarkan hasil uji statistik (Tabel 10) didapatkan nilai $\mathrm{p}=0,001$ yang menunjukkan bahwa terdapat hubungan bermakna antara tingkat pengetahuan dan status periodontal pada penyandang DMT2 di RSUD Bitung. Hasil penelitian tersebut sama dengan penelitian yang dilakukan oleh Merdeka ${ }^{18}$ yang menyebutkan bahwa terdapat hubungan antara tingkat pengetahuan dan status periodontal pada pasien DMT2.

Penyandang DMT2 sangat penting untuk meningkatkan pengetahuan mengenai kebersihan gigi dan mulut agar dapat melakukan hal-hal yang baik pada kesehatannya. Pengetahuan yang dimaksud yaitu pengetahuan tentang cara menjaga kesehatan gigi dan mulut, dengan demikian akan menimbulkan perilaku hidup sehat sesuai dengan pengetahuan yang penderita dimilikinya.

\section{SIMPULAN}

Berdasarkan hasil penelitian yang dilakukan di RSUD Bitung maka dapat dibuat kesimpulan sebagai berikut:

1. Tingkat pengetahuan pasien DMT2 di RSUD Bitung tergolong kurang baik.

2. Status kesehatan jaringan periodontal pasien DMT2 di RSUD Bitung umumnya tergolong gingivitis.

3. Terdapat hubungan antara tingkat pengetahuan dan status kesehatan jaringan periodontal pada pasien DMT2 di RSUD Bitung.

\section{SARAN}

1. Disarankan agar data hasil penelitian dapat digunakan oleh pihak RSUD Bitung dalam penyusunan program peningkatan kesehatan bagi para penderita yang dirawat, yakni berupa upaya pendidikan kesehatan bagi masyarakat rumah sakit (PKMRS)

2. Disarankan bagi pihak rumah sakit agar rujukan antar poliklinik penyakit dalam dan poliklinik gigi dan mulut ditingkatkan untuk keberhasilan perawatan dan pemulihan kesehatan penderita DMT2 secara keseluruhan.

3. Disarankan kepada pihak pemerintah dalam hal ini pusat-pusat kesehatan masyarakat yang bertanggung jawab atas kesehatan masyarakat di wilayah kerjanya, untuk terus meningkatkan pengetahuan masyarakat dalam bidang kesehatan termasuk kesehatan gigi dan mulut lewat penyuluhan atau pendidikan kesehatan guna mencapai derajat kesehatan yang setinggitingginya.

4. Disarankan kepada pasien DMT2 untuk rajin mengkontrol gula darah dan kesehatan gigi dan mulutnya tiap 6 bulan sekali, dan menjaga kebersihan gigi dan mulutnya dengan cara menyikat gigi yang baik dan benar.

\section{DAFTAR PUSTAKA}

1. Wold Health Organization. Definisi Sehat [online] 2006. [cited 16 Maret 2016]. Available from: http://www. who.int/about/definition/en/print.html.

2. Riset Kesehatan Dasar. Badan penelitian dan pengembangan kesehatan. Jakarta: Kementrian Kesehatan Republik Indonesia, 2014; p. 143.

3. Tampubolon SN. Dampak karies gigi dan penyakit periodontal terhadap kualitas hidup [online]. [cited 16 Maret 2016]. Available http://library.usu.ac.id.

from:

. Negrato CA, Tarzia O, Jovanovic L, Chinellato LDM. Periodontal disease and diabetes mellitus. J Appl Oral Sci. 
2013;21(1):1-12.

5. Depertemen Kesehatan. Pharmaceutical care untuk penyakit diabetes melitus [online]. 2005. [cited 16 Maret 2016].

6. Rikawarastuti, Anggreni E, Ngatemi, Diabetes melitus dan tingkat keparahan jaringan periodontal. Kesmas. 2015;9(3): 277-81.

7. Alifanti. D. Hubungan timbal balik antara periodontitis dengan diabetes melitus [online]. [cited 16 Maret 2016]. Available from: https://www. academia.edu.

8. Eldarrat AH. Diabetics patients: Their knowledge and perception of oral health. Libyan J Med. 2011;6:10.3402/ljm.v6i0.5691.

9. Nandya, Maduratna ES, Augustina EF. Status kesehatan jaringan periodontal pada pasien diabetes melitus tipe 2 dibandingkan dengan pasien non diabetes melitus berdasarkan GPI. Surabaya: Fakultas Kedokteran Gigi Universitas Airlangga; 2012.

10.Emor FS, Pandelaki K, Hubungan status periodontal dan derajat regulasi gula darah pasien diabetes melitus di rumah sakit umum pusat Prof Dr. R. D. Kandow Manado. eGiGi. 2015; 3(1):210-5.

11.Herijulianti E, Indriani TS, Antini S. Pendidikan kesehatan gigi. [online]. 2011. Jakarta; p. 2

12.Destiya DH. Efektivitas Menyikat gigi metode horizontal, vertical, dan roll terhadap penurunan plak. Detino Jurnal. 2014; 2(2).

13.Fitriyani. Tingkat pengetahuan mengenai menggosok gigi pada siswa-siswi kelas IV SD kelurahan cirendeu [Skripsi]. Jakarta: Universitas Islam Negeri Syarif Hidayatullah; 2009.

14. Notoatmodjo S. Ilmu Kesehatan Masyarakat. Jakarta: Rineka cipta, 2003; p. 127-8.

15.Anthonie A. Gambaran penyakit gingivitis ditinjau dari kebersihan gigi dan mulut pada pasien yang berkunjung ke rumah sakit ibu dan anak [Skripsi]. Banda Aceh: Universitas Syiah Kuala; 2011.

16.Daliemunthe SH. Hubungan periodontitis dengan diabetes melitus serta perawatannya. Dentika J dent. 2003; 2:120-5.

17.Kartimah DS. Xerostomia pada penderita DM karena neuropati diabetika glosofaringeal. PDGI J. 2006;56 (2):53-100.

18. Merdeka ARP. Hubungan antara Tingkat pengetahuan kesehatan rongga mulut dan status kesehatan jaringan periodontal penderita DMT2 terkontrol pasien rawat jalan di RS pertamina cilacap [Skripsi]. Surakarta: Univerisitas Muhammadiyah; 2015. 